\title{
Caffeic acid improves cell viability and protects against DNA damage: involvement of reactive oxygen species and extracellular signal-regulated kinase
}

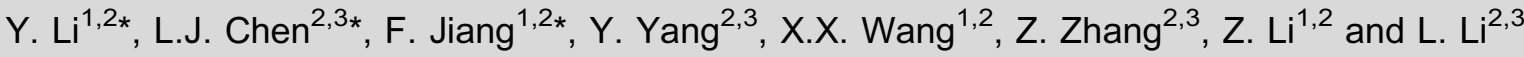 \\ ${ }^{1}$ Department of Nutrition and Food Hygiene, School of Public Health, Nanjing Medical University, Nanjing, China \\ ${ }^{2}$ Department of Hygiene Analysis and Detection, School of Public Health, Nanjing Medical University, Nanjing, China \\ ${ }^{3}$ The Key Laboratory of Modern Toxicology, Ministry of Education, School of Public Health, \\ Nanjing Medical University, Nanjing, China
}

\begin{abstract}
Hormesis is an adaptive response to a variety of oxidative stresses that renders cells resistant to harmful doses of stressing agents. Caffeic acid $(\mathrm{CaA})$ is an important antioxidant that has protective effects against DNA damage caused by reactive oxygen species (ROS). However, whether CaA-induced protection is a hormetic effect remains unknown, as is the molecular mechanism that is involved. We found that a low concentration $(10 \mu \mathrm{M})$ of $\mathrm{CaA}$ increased human liver $\mathrm{L}-02$ cell viability, attenuated hydrogen peroxide $\left(\mathrm{H}_{2} \mathrm{O}_{2}\right)$-mediated decreases in cell viability, and decreased the extent of $\mathrm{H}_{2} \mathrm{O}_{2}$-induced DNA double-strand breaks (DSBs). In L-02 cells exposed to $\mathrm{H}_{2} \mathrm{O}_{2}$, CaA treatment reduced $\mathrm{ROS}$ levels, which might have played a protective role. CaA also activated the extracellular signal-regulated kinase (ERK) signal pathway in a time-dependent manner. Inhibition of ERK by its inhibitor U0126 or by its specific small interfering RNA (siRNA) blocked the CaA-induced improvement in cell viability and the protective effects against $\mathrm{H}_{2} \mathrm{O}_{2}$-mediated DNA damage. This study adds to the understanding of the antioxidant effects of CaA by identifying a novel molecular mechanism of enhanced cell viability and protection against DNA damage.
\end{abstract}

Key words: Caffeic acid; Hormesis; Antioxidants; DNA double-strand breaks; Extracellular signal-regulated kinase

\section{Introduction}

Caffeic acid (3,4-dihydroxycinnamic acid, CaA), a naturally occurring hydroxycinnamic acid derivative, is an active phenolic component of propolis extract and is also found in a wide variety of plants (1). It has biological and pharmacological properties that include antiviral, antioxidant, anti-inflammatory, anticarcinogenic, and immunomodulatory activity (1-5). Extensive evidence from both in vitro and in vivo studies suggests that $\mathrm{CaA}$ is an important antioxidant and has health benefits $(2,4)$. CaA can inhibit lipoxygenase activity and suppress lipid peroxidation (2). Moreover, CaA alleviates alcohol-induced oxidative damage in the liver and kidney (6). It can also protect against UVB-induced DNA damage by suppressing the activation of interleukin-10 and mitogen-activated protein kinases (MAPKs) (1). However, the molecular mechanisms underlying the $\mathrm{CaA}$-induced protective effects against DNA damage remain unclear.
The MAPK pathways transduce signals that lead to diverse cellular responses such as cell growth, differentiation, proliferation, and apoptosis (7-9). Each of the three major MAPK pathways consists of three-tiered cascades that induce a pathway comprised of phosphorylating proteins that mediate transduction pathways activated by a variety of extracellular signals and regulate the expression of specific genes $(10,11)$. The extracellular signal-regulated kinase (ERK) pathway typically transduces growth factor signals that induce cell differentiation or proliferation, whereas cytokines and stress signals activate the c-Jun N-terminal kinase (JNK) and p38 MAPK pathways, resulting in stress responses, growth arrest, or apoptosis $(9,12)$. A previous study indicated that $\mathrm{CaA}$ regulates lipopolysaccharide (LPS)-induced oxidative stress through c-Src/ERK signaling pathways in endothelial cells (4). We therefore hypothesized that ERK signaling

Correspondence: Lei Li: < drleili@hotmail.com>.

${ }^{\star}$ These authors contributed equally to this study. 
might be involved in $\mathrm{CaA}$-induced protection against DNA damage.

We found that CaA activated the ERK signaling pathway by a relatively low level of reactive oxygen species (ROS), which blocked $\mathrm{H}_{2} \mathrm{O}_{2}$-induced DNA double-strand breaks (DSBs), and improved the viability of human liver cells. Our study revealed a novel mechanism of CaAinduced protection against DNA damage in liver cells, which may help identify potential targets for the antioxidant and anticarcinogenic activities of CaA.

\section{Material and Methods}

\section{Reagents}

RPMI-1640 medium, fetal bovine serum (FBS), penicillin, and streptomycin were all purchased from Gibco Life Technologies (USA). CaA ( $\geqslant 99 \%$ purity), $\mathrm{H}_{2} \mathrm{O}_{2}$, and catalase were purchased from Sigma (USA). The ERK inhibitor U0126 was purchased from Cell Signaling Technology (USA). All other reagents were of analytical grade or the highest grade available.

\section{Cells and cell culture}

The human liver cell line L-02 was obtained from the Shanghai Institute of Cell Biology, Chinese Academy of Sciences (China). Cells were maintained in $5 \% \mathrm{CO}_{2}$ at $37^{\circ} \mathrm{C}$ in RPMI-1640 medium supplemented with $10 \%$ FBS, $100 \mathrm{U} / \mathrm{mL}$ penicillin, and $100 \mu \mathrm{g} / \mathrm{mL}$ streptomycin.

\section{Determination of cell viability}

Cell viability was evaluated by WST-8 [2-(2-methoxy-4nitrophenyl)-3-(4-nitrophenyl)-5-(2,4-disulfophenyl)-2H-tetrazolium sodium salt] hydrolysis using a cell counting kit (CCK-8, Dojindo Molecular Technologies, Inc., Japan). Briefly, cells were seeded in 96-well plates in triplicate at a concentration of $2 \times 10^{3}$ per well for $24 \mathrm{~h}$. The plates were treated as indicated in the figure legends. Following treatment, $10.0 \mu \mathrm{L}$ CCK-8 solution was added to each well, and the cells were incubated for another $4 \mathrm{~h}$. Absorbance at $450 \mathrm{~nm}$ was measured with a multiwell plate reader (Model 680 , Bio-Rad, USA). Cell viability was calculated as the ratio of the absorbance of experimental and control wells, which contained only cells and medium, and is reported as a percentage.

\section{Measurement of intracellular ROS}

Intracellular ROS levels were quantified by using the DCFDA (2', 7' -dichloro fluorescein diacetate)-Cellular Reactive Oxygen Species Detection Assay Kit (Abcam, UK). DCFDA was oxidized by ROS in viable cells to $2^{\prime}, 7^{\prime}$-dichloro fluorescein (DCF), which is highly fluorescent at $530 \mathrm{~nm}$. The cells were washed three times with phosphate-buffered saline (PBS). DCFDA, diluted to a final concentration of $10 \mu \mathrm{M}$, was added, and the cells were incubated for $30 \mathrm{~min}$ at $37^{\circ} \mathrm{C}$ in the dark. After washing three times with PBS, fluorescence was measured with a multimode microplate reader (Tecan Trading AG, Switzerland) at excitation and emission wavelengths of 488 and $525 \mathrm{~nm}$, respectively. ROS level was calculated as the absorbance ratio of experimental and control cells and expressed as a percentage.

\section{Western blots}

Cell lysates were subjected to sodium dodecyl sulfatepolyacrylamide gel electrophoresis (SDS-PAGE), and proteins were transferred to polyvinylidene fluoride (PVDF) membranes (Millipore, USA), which were probed with primary antibodies (1:500 dilution) overnight at $4^{\circ} \mathrm{C}$. The antibodies used were ERK and p-ERK (Cell Signaling Technology) and glyceraldehyde 3-phosphate dehydrogenase (GAPDH, Sigma). Membranes were then incubated with horseradish peroxidase-conjugated secondary antibodies (1:1000 dilution, Cell Signaling Technology) for $1 \mathrm{~h}$ at room temperature. The immune complexes were detected with enhanced chemiluminescence reagents (Cell Signaling Technology). Blots were quantified by densitometry and normalized against GAPDH to correct for differences in protein loading. For densitometric analyses, the bands on the blots were measured with the Eagle Eye II imaging system (Stratagene, USA).

\section{RNA interference}

Control, ERK1, and ERK2 small interfering RNAs (siRNA) were purchased from Santa Cruz Biotechnology (USA). Transfections were performed with the N-TERTM Nanoparticle siRNA Transfection System (Sigma). Briefly, $1 \times 10^{6}$ cells were seeded into each well of 6 -well plates and cultured for $48 \mathrm{~h}$. Transfection was carried out for $12 \mathrm{~h}$ after adding a nanoparticle formation solution containing $20 \mathrm{nM}$ target siRNA to each well. The cells were then maintained in conventional cultures for $24 \mathrm{~h}$ before conducting further experiments.

\section{Statistical analysis}

Derived values are reported as the means with $95 \%$ confidence intervals (Cls). Student's $t$-tests and one-way analyses of variance (ANOVAs) followed by Dunnett's $t$-tests were used to assess significant differences among groups. $P$ values $<0.05$ were considered statistically significant. All tests were carried out with SPSS software (version 11.5; SPSS Inc., USA).

\section{Results}

\section{$\mathrm{CaA}$ attenuated $\mathrm{H}_{2} \mathrm{O}_{2}$-induced inhibition of cell viability of L-02 cells}

We first determined the effects of $\mathrm{CaA}$ on cell viability. Human liver L-02 cells were treated with $0,5,10,20,40,80$, or $160 \mu \mathrm{M} \mathrm{CaA}$ for 12,24 , or $48 \mathrm{~h}$. As shown in Figure $1 \mathrm{~A}$, cell viability increased after treatment with 10 and $20 \mu \mathrm{M}$ $\mathrm{CaA}$; however, there were marked decreases at 40,80 , and $160 \mu \mathrm{M}$ CaA. Cell viability reached a peak at $10 \mu \mathrm{M} \mathrm{CaA}$ 

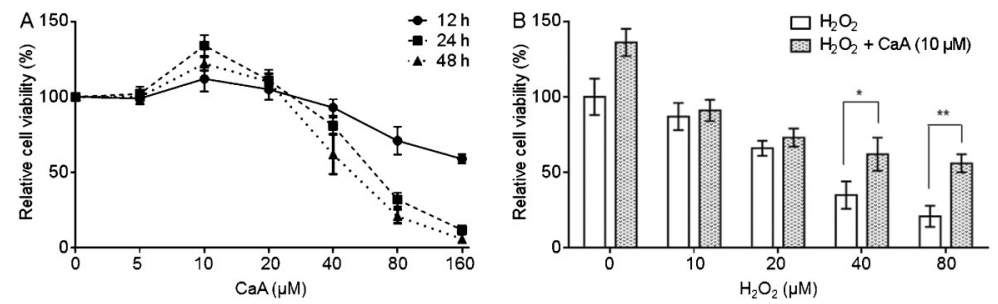

Figure 1. Caffeic acid (CaA) attenuated the $\mathrm{H}_{2} \mathrm{O}_{2}$-induced inhibition of L-02 cell viability. $A$, L-02 cells were treated with $0,5,10,20,40,80$, or $160 \mu \mathrm{M} \mathrm{CaA}$ for 12,24 , or $48 \mathrm{~h}$. B, After pretreatment of L-02 cells with 0 or $10 \mu \mathrm{M} \mathrm{CaA}$ for $24 \mathrm{~h}$, they were exposed to $0,10,20,40$, or $80 \mu \mathrm{M} \mathrm{H}_{2} \mathrm{O}_{2}$ for $24 \mathrm{~h}$. Cell viability was measured by cell counting and comparison with control cells treated with culture medium only. ${ }^{*} \mathrm{P}<0.05$ and ${ }^{* *} \mathrm{P}<0.01$ compared with $\mathrm{L}-02$ cells treated only with $\mathrm{H}_{2} \mathrm{O}_{2}$ (Student's $t$-test). and then declined with increasing concentrations, so $10 \mu \mathrm{M}$ was chosen for further investigation. We next exposed L-02 cells to $\mathrm{H}_{2} \mathrm{O}_{2}$, which induces oxidative stress and generates DSBs, and further evaluated the antioxidant effects induced by a low concentration of $\mathrm{CaA}$. As shown in Figure $1 \mathrm{~B}, \mathrm{H}_{2} \mathrm{O}_{2}$ decreased cell viability in a dose-dependent manner, but $\mathrm{CaA}$ attenuated the $\mathrm{H}_{2} \mathrm{O}_{2}$-mediated inhibition of cell viability, suggesting that hormesis induced by a low concentration of $\mathrm{CaA}$ attenuated the decrease in L-02 cell viability induced by $\mathrm{H}_{2} \mathrm{O}_{2}$.

CaA decreased the $\mathrm{H}_{2} \mathrm{O}_{2}$-induced DSBs in $\mathrm{L}-02$ cells

Oxidative DNA damage is the leading cause of decreased cell viability $(13,14)$. We exposed L-02 cells to $0,10,20,40$, or $80 \mu \mathrm{M} \mathrm{H} \mathrm{O}_{2}$ for $6 \mathrm{~h}$ and found dosedependent increases in the expression of $\gamma-\mathrm{H} 2 \mathrm{AX}$, which is a biomarker of DSBs (Figure $2 \mathrm{~A}$ and $\mathrm{B}$ ). We then evaluated the ability of $\mathrm{CaA}$ to protect against the DNA damage that resulted from $\mathrm{H}_{2} \mathrm{O}_{2}$ treatment. After pretreating L-02 cells
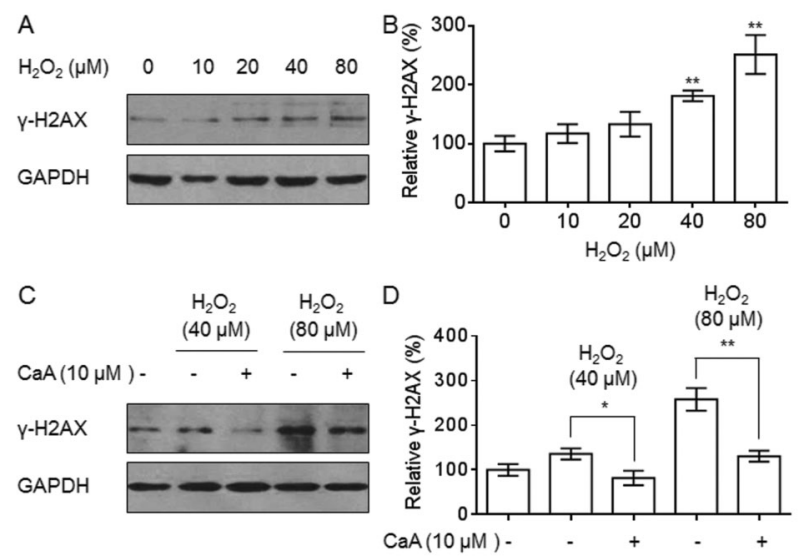

Figure 2. Caffeic acid $(\mathrm{CaA})$ decreased $\mathrm{H}_{2} \mathrm{O}_{2}$-induced doublestrand breads (DSBs) in L-02 cells. $A, B, \mathrm{~L}-02$ cells were exposed to $0,10,20,40$, or $80 \mu \mathrm{M} \mathrm{H}_{2} \mathrm{O}_{2}$ for 6 h. $A$, Western blot analysis and $B$, relative $\gamma-\mathrm{H} 2 \mathrm{AX}$ protein levels. ${ }^{* *} \mathrm{P}<0.01$ compared with control cells. $C, D, \mathrm{~L}-02$ cells were pretreated with 0 or $10 \mu \mathrm{M} \mathrm{CaA}$ for $24 \mathrm{~h}$ and then exposed to 40 (lanes 2 and 3) or 80 (lanes 4 and 5) $\mu \mathrm{M}$ $\mathrm{H}_{2} \mathrm{O}_{2}$ for $6 \mathrm{~h}$. $C$, Western blot analysis and $D$, relative $\gamma-\mathrm{H} 2 \mathrm{AX}$ protein levels. ${ }^{*} \mathrm{P}<0.05$ and ${ }^{* *} \mathrm{P}<0.01$ compared with $\mathrm{L}-02$ cells treated with $\mathrm{H}_{2} \mathrm{O}_{2}$ alone (Student's $t$-test). Bands were normalized to glyceraldehyde 3-phosphate dehydrogenase (GAPDH). with 0 or $10 \mu \mathrm{M} \mathrm{CaA}$ for $24 \mathrm{~h}$, they were exposed to 40 or $80 \mu \mathrm{M}$ of $\mathrm{H}_{2} \mathrm{O}_{2}$ for $6 \mathrm{~h}$. As shown in Figure $2 \mathrm{C}$ and $\mathrm{D}, \mathrm{CaA}$ attenuated the $\mathrm{H}_{2} \mathrm{O}_{2}$-induced increase in $\gamma$ - $\mathrm{H} 2 \mathrm{AX}$ expression. These results indicate that a low concentration of $\mathrm{CaA}$ decreased $\mathrm{H}_{2} \mathrm{O}_{2}$-induced DSBs in L-02 cells.

\section{CaA decreased ROS levels in L-02 cells}

ROS have been implicated in a number of processes including cell proliferation, DNA damage, and apoptosis $(9,11,14)$. At low levels, ROS modulate gene expression by acting as second messengers, but at high levels they cause oxidative injury leading to cell death $(13,15)$. We hypothesized that the $\mathrm{CaA}$-induced improvement of cell viability and protection against DNA damage following $\mathrm{H}_{2} \mathrm{O}_{2}$ treatment were mediated by the generation of low levels of ROS. To confirm our hypothesis, L-02 cells were exposed to $10 \mu \mathrm{M}$ CaA for $0,3,6,12,24$, or $48 \mathrm{~h}$. As shown in Figure 3, the ROS levels induced by CaA were $112-136 \%$ compared with control cells (100\%); however, in cells treated with $40 \mu \mathrm{M}$ $\mathrm{H}_{2} \mathrm{O}_{2}$, the relative ROS level was $236 \%$. These results suggest that compared with exposure to $\mathrm{H}_{2} \mathrm{O}_{2}, \mathrm{CaA}$ generated relatively lower levels of ROS in L-02 cells.

\section{CaA activated ERK signaling by ROS in L-02 cells}

The ERK pathway typically transduces growth factor signals that lead to cell differentiation or proliferation (7); however, the association of ERK with $\mathrm{CaA}$-induced improvement of cell viability and subsequent protection against DNA damage is unclear. We exposed $L-02$ cells to

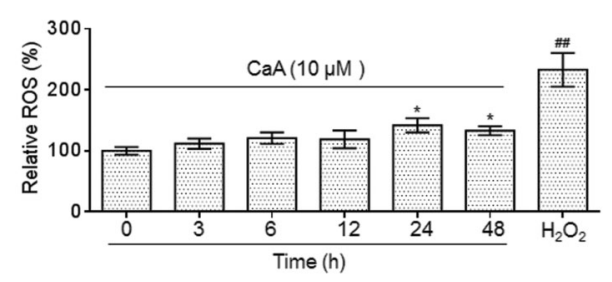

Figure 3. Caffeic acid $(\mathrm{CaA})$ generated relatively lower levels of reactive oxygen species (ROS) in L-02 cells compared to cells treated only with $\mathrm{H}_{2} \mathrm{O}_{2}$. L-02 cells were treated with $10 \mu \mathrm{M} \mathrm{CaA}$ for $0,3,6,12,24$, or $48 \mathrm{~h}$. Cells exposed to $40 \mu \mathrm{M} \mathrm{H}_{2} \mathrm{O}_{2}$ for $24 \mathrm{~h}$ served as positive controls. ROS levels were measured with the DCF fluorescence method. * $\mathrm{P}<0.05$ compared to medium control cells; $\# \# \mathrm{P}<0.01$ compared to medium control cells and to $\mathrm{CaA}$ treatment at all times (one-way ANOVA followed by Dunnett's $t$-test). 

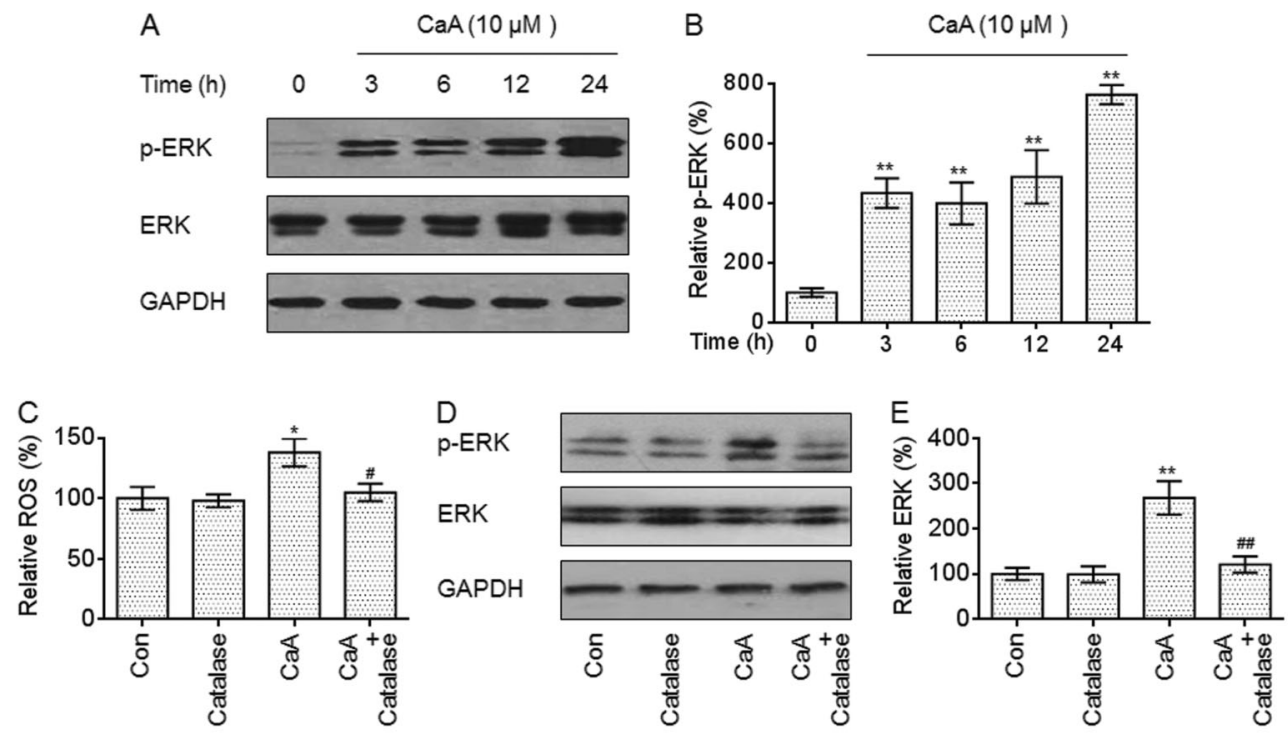

Figure 4. Caffeic acid ( $\mathrm{CaA})$ activated extracellular signal-regulated kinase (ERK) signaling by reactive oxygen species (ROS) in L-02 cells. $A, B, \mathrm{~L}-02$ cells were treated with $10 \mu \mathrm{M} \mathrm{CaA}$ for $0,3,6,12$, or $24 \mathrm{~h}$. $A$, Western blots and $(B)$ relative p-ERK protein levels. $C$ - $E$, $\mathrm{L}-02$ cells were pretreated with $10 \mathrm{nM}$ catalase for $1 \mathrm{~h}$ and then exposed to $10 \mu \mathrm{M} \mathrm{CaA}$ for $24 \mathrm{~h}$. $C$, ROS levels were measured with the DCF fluorescence method. The relative ROS ratios were determined by comparison with control cells. $D$, Western blots and $E$, relative $\mathrm{p}$-ERK levels. ${ }^{*} \mathrm{P}<0.05$ and ${ }^{* *} \mathrm{P}<0.01$ compared with controls; ${ }^{\#} \mathrm{P}<0.05$ and ${ }^{\# \#} \mathrm{P}<0.01$ compared with cells treated with CaA alone (one-way ANOVA followed by Dunnett's $t$-test).

$10 \mu \mathrm{M} \mathrm{CaA}$ for $0,3,6,12$, or $24 \mathrm{~h}$, and found that with increased time of $\mathrm{CaA}$ exposure, there was enhanced expression of $p$-ERK, a biomarker for the activation of ERK signaling (Figure 4A and B). Next, we investigated the mechanisms underlying $\mathrm{CaA}$-induced activation of ERK signaling. L-02 cells were pretreated with $10 \mathrm{nM}$ catalase, an $\mathrm{H}_{2} \mathrm{O}_{2}$ scavenger, for $1 \mathrm{~h}$ and then exposed to $10 \mu \mathrm{M}$ $\mathrm{CaA}$ for $24 \mathrm{~h}$. As shown in Figure 4C-E, ROS scavenging by catalase attenuated both the CaA-induced generation of ROS and ERK activation. These results indicate that $\mathrm{CaA}$ generated a relatively low level of ROS in L-02 cells, which induced sustained activation of the ERK signal pathway. These results suggest that ERK played a role in the CaAinduced improvement of cell viability and protection against DNA damage that are associated with $\mathrm{H}_{2} \mathrm{O}_{2}$ treatment.

\section{Inhibition of ERK blocked CaA-mediated reduction of DSBs}

We found evidence to support our hypothesis that ERK was involved in the CaA-mediated reduction of DSBs in $\mathrm{H}_{2} \mathrm{O}_{2}$-treated L-02 cells. Following pretreatment with 0 or $10 \mu \mathrm{M} \mathrm{CaA}$ in the presence or absence of $10 \mu \mathrm{M} \mathrm{U} 0126$ (an ERK inhibitor) for $24 \mathrm{~h}$, cells were exposed to $80 \mu \mathrm{M} \mathrm{H}_{2} \mathrm{O}_{2}$ for an additional $6 \mathrm{~h}$. As shown in Figure $5 \mathrm{~A}$ and $\mathrm{B}, \mathrm{CaA}$ attenuated the $\mathrm{H}_{2} \mathrm{O}_{2}$-induced increase in $\gamma-\mathrm{H} 2 \mathrm{AX}$ expression. However, inhibition of ERK by U0126 abolished this phenomenon. RNA interference confirmed the effect of ERK inhibition. In L-02 cells, knockdown of ERK1 and ERK2 by their specific siRNAs blocked the CaA-induced attenuation of $\gamma-\mathrm{H} 2 \mathrm{AX}$ expression in response to $\mathrm{H}_{2} \mathrm{O}_{2}$ treatment (Figure $5 \mathrm{C}$ and $\mathrm{D}$ ). These results indicate that the ERK signaling pathway was involved in $\mathrm{CaA}$-induced protection against DNA damage by $\mathrm{H}_{2} \mathrm{O}_{2}$ treatment.

\section{Inhibition of ERK blocked the CaA-induced improvement of cell viability in $\mathrm{H}_{2} \mathrm{O}_{2}$-treated L-02 cells}

Finally, we demonstrated that ERK was involved in the CaA-induced improvement in the viability of cells treated with $\mathrm{H}_{2} \mathrm{O}_{2}$. $\mathrm{L}-02$ cells were treated as described above for $24 \mathrm{~h}$. As shown in Figure 6, CaA attenuated the $\mathrm{H}_{2} \mathrm{O}_{2-}$ induced decrease in cell viability; however, inhibition of ERK by U0126 or siRNA abolished this effect. These results indicate that the ERK signaling pathway was involved in the $\mathrm{CaA}$-induced improvement of cell viability.

\section{Discussion}

Hydroxycinnamic acid derivatives are reported to have anticancer, anti-inflammatory, and antioxidant activities, and $\mathrm{CaA}$ is a well known hydroxycinnamic acid (16). Previous studies have demonstrated that daily coffee intake was associated with a reduced incidence of colon and rectal cancer. Michels et al. (17) reported that participants who regularly consumed two or more cups of decaffeinated coffee per day had a $52 \%$ lower incidence of rectal cancer than those who never consumed it. Tavani et al. (18) found that compared with coffee nondrinkers, the risk of colon 

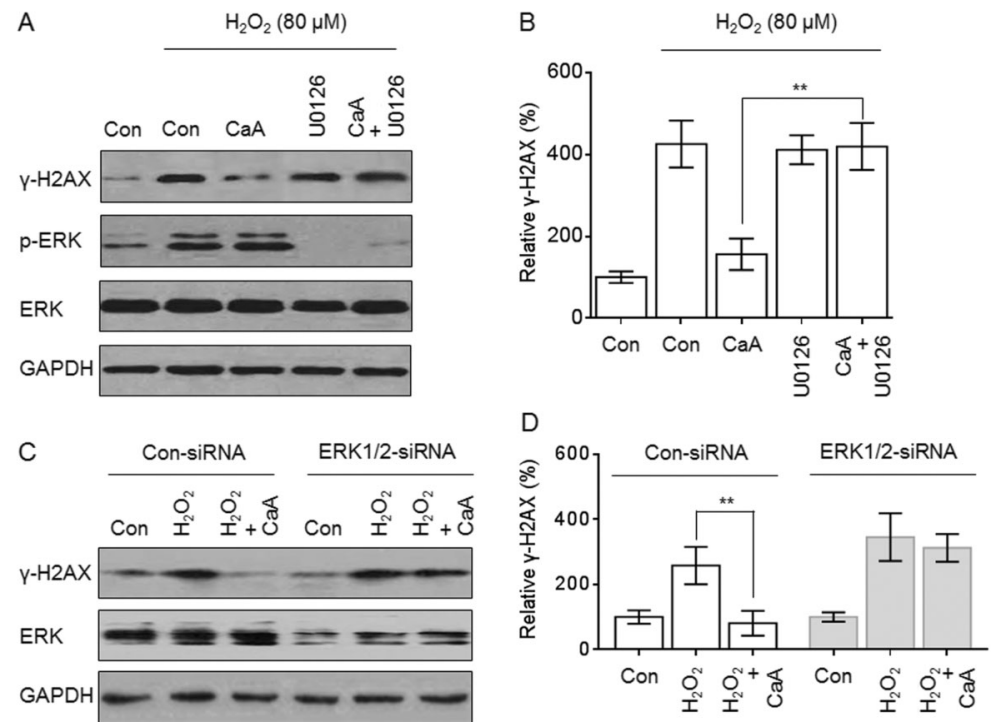

Figure 5. Extracellular signal-regulated kinase (ERK) inhibition blocked the caffeic acid (CaA)induced reduction in double-strand breads (DSBs) in human L-02 cells. $A, B$, After pretreatment with 0 or $10 \mu \mathrm{M} \mathrm{CaA}$ in the presence or absence of $\mathrm{U} 0126(10 \mu \mathrm{M})$ for $24 \mathrm{~h}$, they were exposed to $80 \mu \mathrm{M} \mathrm{H}_{2} \mathrm{O}_{2}$ for $24 \mathrm{~h}$. $A$, Western blots and $B$, relative $\gamma-\mathrm{H} 2 \mathrm{AX}$ protein levels. ${ }^{* *} \mathrm{P}<0.01$ compared with $\mathrm{L}-02$ cells treated with CaA plus $\mathrm{H}_{2} \mathrm{O}_{2}$. C, D, After L-02 cells were transfected with 20 nM ERK1-siRNA plus ERK2siRNA for $12 \mathrm{~h}$, they were treated with 0 or $10 \mu \mathrm{M}$ $\mathrm{CaA}$ for $24 \mathrm{~h}$, followed by exposure to $80 \mu \mathrm{M}$ $\mathrm{H}_{2} \mathrm{O}_{2}$ for an additional 24 h. C, Western blots and $D$, relative $\gamma-\mathrm{H} 2 \mathrm{AX}$ protein levels. ${ }^{* *} \mathrm{P}<0.01$ compared with L-02 cells treated by $\mathrm{H}_{2} \mathrm{O}_{2}$ alone (one-way ANOVA followed by Dunnett's $t$-test).
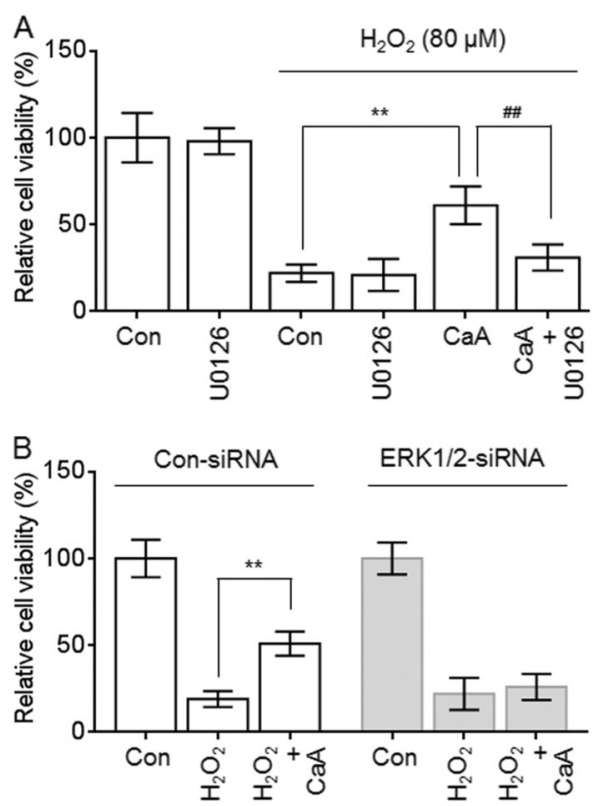

Figure 6. Extracellular signal-regulated kinase (ERK) inhibition blocked the caffeic acid $(\mathrm{CaA})$-induced improvement of cell viability in $\mathrm{H}_{2} \mathrm{O}_{2}$-treated $\mathrm{L}-02$ cells. $A$, After pretreatment with 0 or $10 \mu \mathrm{M} \mathrm{CaA}$ in the presence or absence of U0126 $(10 \mu \mathrm{M})$ for $24 \mathrm{~h}$, they were exposed to $80 \mu \mathrm{M} \mathrm{H}_{2} \mathrm{O}_{2}$ for an additional $24 \mathrm{~h}$. Cell viability was measured by cell counting. Relative cell viability was determined by comparison with control cells. ${ }^{* *} \mathrm{P}<0.01$ compared with $\mathrm{L}-02$ cells treated with $\mathrm{H}_{2} \mathrm{O}_{2}$ alone. ${ }^{\# \#} \mathrm{P}<0.01$ compared with $\mathrm{L}-02$ cells treated with $\mathrm{CaA}$ plus $\mathrm{H}_{2} \mathrm{O}_{2}$. $\mathrm{B}$, After $\mathrm{L}-02$ cells were transfected by $20 \mathrm{nM}$ ERK1 plus ERK2 siRNA for $12 \mathrm{~h}$, they were treated with 0 or $10 \mu \mathrm{M} \mathrm{CaA}$ for $24 \mathrm{~h}$, followed by exposure to $80 \mu \mathrm{M} \mathrm{H}_{2} \mathrm{O}_{2}$ for an additional $24 \mathrm{~h}$. Cell viability was measured by cell counting. ${ }^{*} \mathrm{P}<0.01$ compared with $\mathrm{L}-02$ cells treated with $\mathrm{H}_{2} \mathrm{O}_{2}$ alone (one-way ANOVA followed by Dunnett's $t$-test). cancer was reduced in drinkers of four or more cups per day. In most coffee drinkers, the daily intake of $\mathrm{CaA}$ is $0.5-1 \mathrm{~g}$ (approximately $0.5-1 \mathrm{mM}$ ), and the absorption ratio of $\mathrm{CaA}$ is about $95 \%$. Some of the $\mathrm{CaA}$ in food enters the circulation, but most passes into the colon (19), so here we used a relatively low concentration of $\mathrm{CaA}(10 \mu \mathrm{M})$ to assess its ability to protect against DNA damage and maintain cell viability after $\mathrm{H}_{2} \mathrm{O}_{2}$ treatment.

The present study employed L-02 cells because i) hepatocellular carcinoma, the most common liver malignancy, is a global health problem (20); ii) CaA protects against liver lesions and carcinogenesis in humans $(21,22)$; and iii) the liver is thought to be the most important organ for CaA metabolism. Identification of the molecular mechanisms underlying the CaA-induced effects on cell viability and DNA damage would add to our understanding of the anti-oncogenetic effects of CaA.

Biphasic dose-response relationships have recently received considerable attention $(23,24)$. They are characterized by stimulation of chemical agents at low doses (hormesis) and inhibition at high doses (25). Hormesis, also known as oxidative stress adaptation, is an important mechanism by which cells and organisms respond to and cope with environmental and physiological shifts in oxidative stress levels (25). The accumulated evidence for hormesis of chemical agents derives from three different areas: cell proliferation or viability, DNA base excision repair, and telomerase activity (25-27). Here, we established that low levels of $\mathrm{CaA}$ act as a hormesis trigger to improve cell viability and protect against DNA damage caused by $\mathrm{H}_{2} \mathrm{O}_{2}$ treatment.

$\mathrm{ROS}$, such as superoxide anions, $\mathrm{H}_{2} \mathrm{O}_{2}$, and hydroxyl radicals, are ubiquitous, highly reactive, diffusible molecules $(16,28)$. It has long been recognized that ROS cause complex and irreversible damage to cellular constituents that impairs cellular homeostasis (15). Oxidative damage 


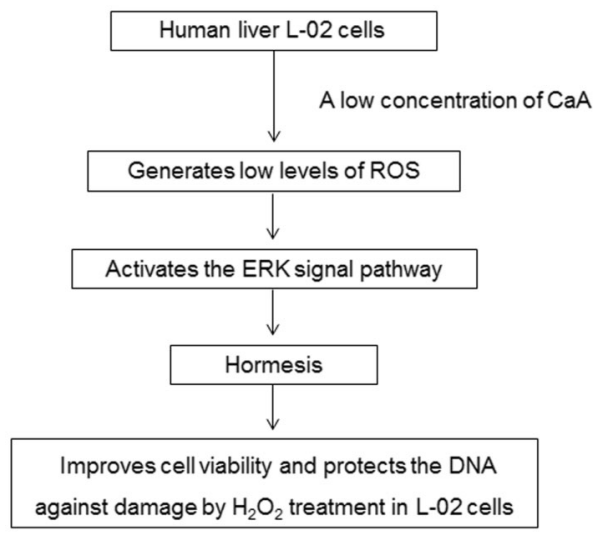

Figure 7. Caffeic acid (CaA)-induced improvement of cell viability and protection against DNA damage: involvement of reactive oxygen species (ROS) and extracellular signal-regulated kinase (ERK) signaling.

is related to the high reactivity of molecular oxygen and its intermediates, which can lead to oxidative modifications of proteins, lipids, and DNA (15). A role for oxidative damage to DNA in carcinogenesis is consistent with accumulating evidence that the rate of genome instability increases with age $(4,14)$. Recent studies suggest that the enhanced ROS generation without cytotoxicity has a cellular protective effect $(15,27)$. On the other hand, marked ROS formation causes oxidative stress and cellular damage $(16,29)$. Here we found that compared with cells exposed to $\mathrm{H}_{2} \mathrm{O}_{2}$, a low concentration of $\mathrm{CaA}$-generated ROS may play a protective role in L-02 cells. These results are in line with previous findings that sodium arsenite acts as a hormesis trigger at low concentrations and induced enhanced ROS generation without cytotoxicity and had a cellular protective effect (15).

ROS can trigger the activation of redox-sensitive signal transduction and MAPK pathways that regulate cellular mechanisms of cell survival, death, and immunity $(9,30,31)$. MAPKs including ERK, p38 MAPK, and JNK are key components of signaling pathways that control cell differentiation and growth $(9,30,31)$. There is evidence that MAPKs can be phosphorylated and activated in response to

\section{References}

1. Kang NJ, Lee KW, Shin BJ, Jung SK, Hwang MK, Bode AM, et al. Caffeic acid, a phenolic phytochemical in coffee, directly inhibits Fyn kinase activity and UVB-induced COX-2 expression. Carcinogenesis 2009; 30: 321-330, doi: 10.1093/carcin/bgn282.

2. Karthikesan K, Pari L. Beneficial effect of caffeic Acid on alcohol-induced alterations in lipid peroxidation and antioxidant defense in rats. Toxicol Mech Methods 2007; 17: $527-$ 534, doi: 10.1080/15376510701410476.

3. Khan AQ, Khan R, Qamar W, Lateef A, Ali F, Tahir M, et al. Caffeic acid attenuates 12-O-tetradecanoyl-phorbol-13acetate (TPA)-induced NF-kappaB and COX-2 expression oxidant-induced alterations of the redox state (7). After activation, each MAPK phosphorylates a distinct spectrum of substrates including key regulatory enzymes, cytoskeletal proteins, regulators of apoptosis, nuclear receptors, and many transcription factors that bind to specific DNA sequences and induce transcriptional activation and DNA synthesis, with cellular recruitment to the S-phase $(9,30,32)$. $\mathrm{CaA}$ regulates $\mathrm{LPS}$-induced oxidative stress through $\mathrm{c}-\mathrm{Src} /$ ERK signaling pathways in endothelial cells (4). Notably, the ERK signal pathway is involved in the improvement of cell viability induced by a low concentration of sodium arsenite, a hormesis trigger (33). Here we found that a low concentration of $\mathrm{CaA}$ induced sustained activation of ERK signaling. Further, we confirmed that the CaA-induced activation of ERK was mediated by ROS generation. Based on these results, we hypothesized that ERK might play a role in CaAinduced improvement of cell viability and protection against DNA damage caused by $\mathrm{H}_{2} \mathrm{O}_{2}$ treatment. To further understand the role of the ERK pathway, we used U0126 and ERK1/2-siRNA to block ERK activation. Inhibition of ERK blocked the CaA-mediated reduction of DSBs and attenuated the $\mathrm{CaA}$-induced improvement of cell viability associated with $\mathrm{H}_{2} \mathrm{O}_{2}$ treatment.

A low concentration of $\mathrm{CaA}$ increased the viability of human liver L-02 cells, attenuated the $\mathrm{H}_{2} \mathrm{O}_{2}$-associated reduction of cell viability, and decreased the occurrence of $\mathrm{H}_{2} \mathrm{O}_{2}$-induced DSBs. Compared with cells exposed to $\mathrm{H}_{2} \mathrm{O}_{2}$, CaA-treated cells generated lower levels of ROS that induced ERK signaling pathway. Inhibition of ERK signaling blocked the CaA-induced improvement of cell viability and protection against DNA damage caused by $\mathrm{H}_{2} \mathrm{O}_{2}$ treatment (Figure 7).

\section{Acknowledgments}

This research was supported by the Natural Science Foundations of China (\#81072338, \#81473020, and \#81402667), a project funded by the Priority Academic Program Development of Jiangsu Higher Education Institutions (2010), and a Technology Development Fund of Nanjing Medical University (\#2013NJMU021). in mouse skin: abrogation of oxidative stress, inflammatory responses and proinflammatory cytokine production. Food Chem Toxicol 2012; 50: 175-183, doi: 10.1016/j.fct.2011. 10.043.

4. Kim SR, Jung YR, Kim DH, An HJ, Kim MK, Kim ND, et al. Caffeic acid regulates LPS-induced NF-kappaB activation through NIK/IKK and c-Src/ERK signaling pathways in endothelial cells. Arch Pharm Res 2014; 37: 539-547, doi: 10.1007/s12272-013-0211-6.

5. Touaibia M, Jean-Francois J, Doiron J. Caffeic Acid, a versatile pharmacophore: an overview. Mini Rev Med Chem 2011; 11: 695-713, doi: 10.2174/138955711796268750. 
6. Pari L, Karthikesan K. Protective role of caffeic acid against alcohol-induced biochemical changes in rats. Fundam Clin Pharmacol 2007; 21: 355-361, doi: 10.1111/j.1472-8206. 2007.00505.x.

7. Ma Y, Jin Z, Huang J, Zhou S, Ye H, Jiang S, et al. IQGAP1 plays an important role in the cell proliferation of multiple myeloma via the MAP kinase (ERK) pathway. Oncol Rep 2013; 30: 3032-3038.

8. Li L, Eun JS, Nepal M, Ryu JH, Cho HK, Choi BY, et al. Isopsoralen induces differentiation of prechondrogenic ATDC5 cells via activation of MAP kinases and BMP-2 signaling pathways. Biomol Ther 2012; 20: 299-305, doi: 10.4062/biomolther.2012.20.3.299.

9. Sun $Y$, Tang S, Jin X, Zhang C, Zhao W, Xiao X. Opposite effects of JNK and p38 MAPK signaling pathways on furazolidone-stimulated $S$ phase cell cycle arrest of human hepatoblastoma cell line. Mutat Res 2013; 755: 24-29, doi: 10.1016/j.mrgentox.2013.04.015.

10. Yang Y, Li Y, Wang K, Wang Y, Yin W, Li L. P38/NFkappaB/snail pathway is involved in caffeic acid-induced inhibition of cancer stem cells-like properties and migratory capacity in malignant human keratinocyte. PLoS One 2013; 8: e58915, doi: 10.1371/journal.pone.0058915.

11. Hao C, Hao W, Wei X, Xing L, Jiang J, Shang L. The role of MAPK in the biphasic dose-response phenomenon induced by cadmium and mercury in HEK293 cells. Toxicol In Vitro 2009; 23: 660-666, doi: 10.1016/j.tiv.2009.03.005.

12. Byun MR, Kim AR, Hwang JH, Kim KM, Hwang ES, Hong JH. FGF2 stimulates osteogenic differentiation through ERK induced TAZ expression. Bone 2014; 58: 72-80, doi: 10. 1016/j.bone.2013.09.024.

13. Haberzettl P, Hill BG. Oxidized lipids activate autophagy in a JNK-dependent manner by stimulating the endoplasmic reticulum stress response. Redox Biol 2013; 1: 56-64, doi: 10.1016/j.redox.2012.10.003.

14. Schumacher B. Transcription-blocking DNA damage in aging: a mechanism for hormesis. Bioessays 2009; 31: 1347-1356, doi: 10.1002/bies.200900107.

15. Yang $P$, He XQ, Peng L, Li AP, Wang XR, Zhou JW, et al. The role of oxidative stress in hormesis induced by sodium arsenite in human embryo lung fibroblast (HELF) cellular proliferation model. J Toxicol Environ Health A 2007; 70: 976-983, doi: 10.1080/15287390701290832.

16. Chung KS, Han G, Kim BK, Kim HM, Yang JS, Ahn J, et al. A novel antitumor piperazine alkyl compound causes apoptosis by inducing RhoB expression via ROSmediated cAbl/p38 MAPK signaling. Cancer Chemother Pharmacol 2013; 72: 1315-1324, doi: 10.1007/s00280-013-2310-y.

17. Michels KB, Willett WC, Fuchs CS, Giovannucci E. Coffee, tea, and caffeine consumption and incidence of colon and rectal cancer. J Natl Cancer Inst 2005; 97: 282-292, doi: 10.1093/jnci/dji039.

18. Tavani A, Pregnolato A, La Vecchia C, Negri E, Talamini R, Franceschi S. Coffee and tea intake and risk of cancers of the colon and rectum: a study of 3,530 cases and 7,057 controls. Int J Cancer 1997; 73: 193-197, doi: 10.1002/(SICI)10970215(19971009)73:2<193::AID-IJC5>3.0.CO;2-R.

19. Olthof MR, Hollman PC, Katan MB. Chlorogenic acid and caffeic acid are absorbed in humans. $J$ Nutr 2001; 131: 66-71.
20. Mun AR, Lee SJ, Kim GB, Kang HS, Kim JS, Kim SJ. Fluoxetine-induced apoptosis in hepatocellular carcinoma cells. Anticancer Res 2013; 33: 3691-3697.

21. Liu Y, Flynn TJ, Ferguson MS, Hoagland EM, Yu LL. Effects of dietary phenolics and botanical extracts on hepatotoxicityrelated endpoints in human and rat hepatoma cells and statistical models for prediction of hepatotoxicity. Food Chem Toxicol 2011; 49: 1820-1827, doi: 10.1016/j.fct.2011.04.034

22. Guerriero E, Sorice A, Capone F, Costantini S, Palladino P, D'ischia $M$, et al. Effects of lipoic acid, caffeic acid and a synthesized lipoyl-caffeic conjugate on human hepatoma cell lines. Molecules 2011; 16: 6365-6377, doi: 10.3390/molecules 16086365.

23. Radak Z, Chung HY, Koltai E, Taylor AW, Goto S. Exercise, oxidative stress and hormesis. Ageing Res Rev 2008; 7: 3442, doi: 10.1016/j.arr.2007.04.004.

24. Wang L, Zou W, Zhong Y, An J, Zhang X, Wu M, et al. The hormesis effect of BDE-47 in HepG2 cells and the potential molecular mechanism. Toxicol Lett 2012; 209: 193-201, doi: 10.1016/j.toxlet.2011.12.014

25. Stebbing AR. Hormesis - the stimulation of growth by low levels of inhibitors. Sci Total Environ 1982; 22: 213-234, doi: 10.1016/0048-9697(82)90066-3.

26. Radak Z, Chung HY, Goto S. Exercise and hormesis: oxidative stress-related adaptation for successful aging. Biogerontology 2005; 6: 71-75, doi: 10.1007/s10522-0047386-7.

27. Kinoshita A, Wanibuchi H, Morimura K, Wei M, Shen J, Imaoka S, et al. Phenobarbital at low dose exerts hormesis in rat hepatocarcinogenesis by reducing oxidative DNA damage, altering cell proliferation, apoptosis and gene expression. Carcinogenesis 2003; 24: 1389-1399, doi: 10.1093/carcin/ bgg079.

28. Strengert M, Jennings R, Davanture S, Hayes P, Gabriel G, Knaus UG. Mucosal reactive oxygen species are required for antiviral response: role of Duox in influenza a virus infection. Antioxid Redox Signal 2014; 20: 2695-2709, doi: 10.1089/ ars.2013.5353

29. Ramyaa P, Padma VV. Ochratoxin-induced toxicity, oxidative stress and apoptosis ameliorated by quercetin--modulation by Nrf2. Food Chem Toxicol 2013; 62: 205-216, doi: 10.1016/j.fct.2013.08.048.

30. Cai DT, Jin H, Xiong QX, Liu WG, Gao ZG, Gu GX, et al. ER stress and ASK1-JNK activation contribute to oridonininduced apoptosis and growth inhibition in cultured human hepatoblastoma HuH-6 cells. Mol Cell Biochem 2013; 379: 161-169, doi: 10.1007/s11010-013-1638-2.

31. Zhang H, Tan S, Wang J, Chen S, Quan J, Xian J, et al. Musashi2 modulates K562 leukemic cell proliferation and apoptosis involving the MAPK pathway. Exp Cell Res 2014; 320: 119-127, doi: 10.1016/j.yexcr.2013.09.009.

32. Achiwa $Y$, Hasegawa K, Udagawa $Y$. Effect of ursolic acid on MAPK in cyclin D1 signaling and RING-type E3 ligase (SCF E3s) in two endometrial cancer cell lines. Nutr Cancer 2013; 65: 1026-1033, doi: 10.1080/01635581.2013.810292.

33. He XQ, Chen R, Yang P, Li AP, Zhou JW, Liu QZ. Biphasic effect of arsenite on cell proliferation and apoptosis is associated with the activation of JNK and ERK1/2 in human embryo lung fibroblast cells. Toxicol Appl Pharmacol 2007; 220: 18-24, doi: 10.1016/j.taap.2006.12.021. 